\title{
MARKET ANALYSIS OF SERBIA'S RASPBERRY SECTOR AND CLUSTER DEVELOPMENT INITIATIVES ${ }^{1}$
}

\author{
Vesna Paraušić2 , Ivana Simeunovićc
}

\begin{abstract}
Summary
Authors analyze competitive strength and weakness of raspberry producers in Serbia and propose key prerequisites of which fulfilling will depend develop of successful cluster initiative in Serbian raspberry sector. The research results indicate that Serbian raspberry growers can develop successful cluster and they can keep leading position in the global market of raspberries, only with following many assumptions, like: (a) better organized marketing channel through the vertically and horizontal integration of all actors in this sector,(b) strengthening specialized cooperatives for raspberry production and associations of raspberry growers, and in the future setting up of producer organisations and associations; (c) inclusion of producers of other berries and producers of processed berries; (d) introducing innovations, scientific knowledge, and research and development in production, processing, packing, logistics, export of raspberries, etc. An analysis is based on case study in Šumadija and Western Serbia region, which is major region in raspberry production in Serbia.
\end{abstract}

Key words: cluster initiative, competitive advantage, raspberry sector, and raspberry value chain.

JEL: $Q 01, Q 13$

\section{Introduction}

Authors investigate the current competition position of Serbia on world's raspberry market, and analyze possibility of crating cluster initiative in this sector, in order to

1 This paper is a part of research projects numbers 46006 (Sustainable Agriculture and Rural Development in the Function of Accomplishing Strategic Objectives of the Republic of Serbia in the Danube Region) financed by the Ministry of Education, Science and Technological Development of the Republic of Serbia (period 2011-2016).

2 Vesna Parausić Ph.D., Research Associate, Institute of Agricultural Economics, Volgina Street no. 15, 11060 Belgrade, Serbia, Phone: +381 116972 847, E-mail: vesna_pa@iep.bg.ac.rs.

3 Ivana Simeunović, Ph. D., Assistant Professor, Belgrade Banking Academy, Faculty for Banking, Insurance and Finance, Zmaj Jovina Street, no. 12, 11000 Belgrade, Serbia, Phone +381 112627 272, E-mail: ivana.simeunovic@bba.edu.rs.

EP 2016 (63) 4 (1417-1431) 
improve growth performance and rural development and also to create sustainable competitive advantage for Serbian raspberry producers and traders on the global market.

The main reason for choosing this research topic is the fact that rural areas in Serbia are characterized by deep poverty (GDP per capita in rural areas is a quarter lower than the national average) (Official Gazette of the Republic of Serbia, no. 15/2011). Also, economic structure of rural areas is highly dependent on primary sector which is still based on natural resource depletion, low labor costs and traditional agriculture, which all have led to a decline in employment, productivity and competitiveness of rural areas (Cvejić et al., 2010; EESC, 2011; Official Gazette of the Republic of Serbia, no. 15/2011).

At the same time, raspberry is export oriented product and one of the most important products in Serbia's agriculture. Growers in Šumadija and Western Serbia region have a high raspberry production and already show some characteristics of cluster networking (concentration of producers and cold storages, recognition of the region in domestic and international market, high export performance, tradition in production), which provides initial and important basis for development of cluster initiatives in the future and increase competitiveness of producers and region (Paraušić, Simeunović, 2015).

\section{Methodology and data sources}

Authors performed desk research and appropriate statistical methods of descriptive statistics using the data from primary and secondary research.

Primary research included survey in the form of interviews conducted among domestic companies, associations of raspberry producers, institutions and organizations relevant to Serbian raspberry sector (Paraušić, Simeunović, 2015). The survey was conducted during 2015, by phone, lasting 30-45 minutes, or through personal contacts.

Secondary research included analysis of statistical sources (SORS; FAOSTAT; ITCInternational Trade Centre), and studying a scientific papers of domestic and foreign authors, as well as numerous documents national and international institutions and organizations.

\section{Basic characteristic of raspberry sector in Serbia}

Raspberries are grown on 11 thousand hectares in Serbia on 45,347 agricultural holdings, dominant family agricultural holdings (SORS, 2012). In the period 20122014 , with average yield per hectare of 5.7 tons, Serbia produced 66,831 tons of raspberries (SORS, 2015).

According to FAOSTAT (Table 1), Serbia is one of the world's largest producers of raspberries. In the five-year period (2009-2013), Serbia is among the top five producers of raspberries in the world.

Table 1. Top five producers of raspberries in the world, 2009-2013

\begin{tabular}{|l|l|r|}
\hline Rank & Countries & Average production of raspberries, tones \\
\hline 1. & Russian Federation & 136,200 \\
\hline
\end{tabular}




\begin{tabular}{|l|l|r|}
\hline 2. & Poland & 108,146 \\
\hline 3. & USA & 89,096 \\
\hline 4. & Serbia & 79,842 \\
\hline 5. & Chile ${ }^{1}$ & 50,981 \\
\hline
\end{tabular}

$/{ }^{1}$ International Raspberry Organization - IRO internal data. Accessed on September 15, 2016.

Source: FAOSTAT, http://faostat3.fao.org/home/E. Accessed on September 15, 2016.

Between 90-95\% of Serbian raspberries is the North American Willamette variety from Oregon and harvest starts in late June and ends in July (SIEPA). Autumn raspberry varieties such as Polka, Polana, Tulameen are gaining ground slowly, as growers start to diversify (Pekić, 2015).

Almost $90 \%$ of Serbia's raspberry production is frozen in cold storage plants, while around $10 \%$ remains in Serbia for use by the processing industry, or is sold in open green markets and supermarkets (SIEPA).

Compared with CEFTA, EU and globally, Serbia is the most competitive in fruit production (mainly raspberry, sour cherry, cherry, plum and quince) and raspberries are one of Serbia's best known and most widely exported fruits (SEEDEV).

The majority of Serbian raspberries are exported frozen (93\%), while a smaller amount is chilled (7\%) and exported fresh (SIEPA). About $90 \%$ of frozen raspberries that are exported from Serbia are Individually Quick Frozen (IQF) (British Columbia).

According to ITC, Serbia is the world's leading exporter of frozen raspberries (Table 2) and the largest provider of frozen raspberry to the Western European markets (dominant export markets are Germany, France, and Belgium).

Table 2. Leading exporters of frozen raspberries $/{ }^{1}$ in the world according to export value, 2011-2015

\begin{tabular}{|l|l|r|r|r|}
\hline Rank & Countries & $\begin{array}{c}\text { Average export values, } \\
\text { US Dollar thousand }\end{array}$ & $\begin{array}{c}\text { Average exported } \\
\text { quantity, tons }\end{array}$ & $\begin{array}{c}\text { Average unit value, } \\
\text { USD/t }\end{array}$ \\
\hline 1. & Serbia & 241,756 & 96,399 & 2.5 \\
\hline 2. & Poland & 171,721 & 101,725 & 1.7 \\
\hline 3. & Chile & 168,394 & 56,320 & 3.0 \\
\hline
\end{tabular}

/I Selected product: 081120 Frozen raspberries, blackberries, mulberries, loganberries, black, white or red currants and gooseberries, uncooked or cooked by steaming or boiling in water, whether or not sweetened

Source: ITC, Trade Map, http://www.trademap.org/Index.aspx, Accessed on September 1, 2016.

According to SORS, raspberry is an important and leading export product of Serbia. In the period 2010-2014, raspberry was among the top 10 Serbian products according to export value (Table 3). 
Table 3. Rank of frozen raspberries (with no sugar added) among the leading Serbian export products, 2010-2015 (according to export value)

\begin{tabular}{|l|c|r|r|r|}
\hline Year & $\begin{array}{l}\text { Rank among the top ten } \\
\text { Serbian export products }\end{array}$ & \multicolumn{1}{c|}{ Quantity, $\mathrm{t}$} & Value, 000 USD & Unit value (USD/kg) \\
\hline 2010 & 7 & $61,494.2$ & $165,578.2$ & 2.69 \\
\hline 2011 & 7 & $73,547.8$ & $176,471.4$ & 2.40 \\
\hline 2012 & 10 & $64,268.1$ & $135,648.0$ & 2.11 \\
\hline 2013 & 10 & $61,416.9$ & $187,357.7$ & 3,05 \\
\hline 2014 & 8 & $73,252.5$ & $236,517.6$ & 3,23 \\
\hline 2015 & 6 & $93,713.6$ & $267,945.4$ & 2,86 \\
\hline
\end{tabular}

Source: SORS, link: http://webrzs.stat.gov.rs/WebSite/Public/ReportResultView.aspx?rptKe $y=$ indId $\% 3 d 170402 I N D 01 \% 262 \% 3 d 201000 \% 2 c 201100 \% 2 c 201200 \% 2 c 201300 \% 2 c 20140$ $0 \% 2 c 201500 \% 2613 \% 3 d \% 2612 \% 3 d 00 \% 2661 \% 3 d 10 \% 266 \% 3 d 1 \% 2 c 2 \% 26$ sAreaId $\% 3 d 170$ 402\%26dType\%3dName\%26lType\%3dSerbianCyrillic

Accessed on September 10, 2016.

The most significant competitor of Serbian in the sector of raspberry is Poland from the aspect of export markets and frozen raspberry export quantities (regarding to ITC data, accessed on September 1, 2016). Poland has a strong tradition of growing raspberries and invests heavily in researching and developing new raspberry cultivars, which has created a strong foundation for the country to grow into one of the world's top exporters of frozen raspberries. With a large semi-processing industrial basis and low costs of production, Poland is Serbia's strongest competitor in Europe's frozen raspberry market. However, like Serbia, Poland still faces challenges with quality-assurance and food-safety standards (British Columbia).

Penn State Extension (http://extension.psu.edu/business/ag-alternatives/horticulture/ fruits/red-raspberry-production, accessed on April 5, 2015) states "raspberry production can be a good fit for small farms, as a small planting of raspberries can provide significant income and equipment needs are quite modest".

In Serbia, there are a large number of "small" farms. According to SORS (2012), average size of farms in Serbia is 5.4 ha and $77.4 \%$ of all agricultural holdings have UAA $<=5$ ha. At the same time, some domestic authors, among other things, points that "economic importance of raspberry consists in a relatively large amount of profit per unit of invested capital and labor, reducing unemployment in much of the Republic of Serbia, better economic development"(Sredojević et al., 2013, page 71).

Entire raspberry supply chain in Serbia has been globally oriented, almost and global food chain performs are better than local food chain regarding resources use (land and labour productivity), wage level and labour relations, creation and distribution of added value and food safety (Stojanović et al., 2015). Global raspberry food chain has took more attention than the fresh (local) raspberry food chain and the main reasons are found in high significance of the global raspberry food chain for the overall economy development, including the activity of rural areas in the Šumadija and Western Serbia 
region (Ibidem).

Keeping all the above in mind, and special importance of raspberry sector for the overall Serbian economy, in the following points authors analyze possibility for develop of cluster initiative in raspberry sector in Sumadija and Western Serbia region, with the aims of improving value chain of raspberry, competitiveness and economic and social development of producers and traders in analyzed region.

The choice of the region is determined by the fact that higher concentration of raspberry production and producers in Serbia are in Šmadija and Western Serbia region. According to SORS (2012, internal data), raspberries in Šumadija and Western Serbia region are grown on 10,513 hectares, which is about $95.2 \%$ of the total land under raspberries in Serbia ${ }^{4}$. Also, large number of agricultural producers of raspberries is concentrated in analyzed region (42,563 producers, which is $93.9 \%$ of total number of Serbian raspberry producers) (Ibidem).

\section{Cluster initiatives as a way for improve market chain and competitiveness in raspberry sector in Serbia}

Important contribution of clusters to creating sustainable competitive advantage of companies (as cluster members) and regions in which the cluster operates is often emphasized in literature. European Commission (EC, 2006, 2008), as part of its innovation policy, sees clusters as factors that highly improve economic growth, innovations and investments, particularly in the sector of small and medium enterprises (SMEs). At the same time, the governments of many developed countries use cluster policy as an instrument for regional development, SMEs sector development, or as an integral part of innovation policy (EC, 2008; Europe Innova, 2008).

In literature cluster understanding relies on Porter's definition of clusters (Sölvell et al., 2003; OECD 2006; Gallup Organization, 2006; US Council on Competitiveness, 2007; World Bank, 2009). According to Porter (1998, page 78) "clusters are geographic concentrations of interconnected companies and institutions in a particular field" or "critical masses in one place, of unusual competitive success in particular fields". In addition, Porter (2008, pages 213-214) defines clusters as "geographic concentration of interconnected companies, specialized suppliers, service providers, firms in related industries, and associated institutions (for example, universities, standards agencies, and trade associations) in particular field that compete but also cooperate".

Porter emphasizes that clusters affect competition in three broad ways (Porter, 1998): (1) by increasing the productivity of companies based in the area; (2) by driving the direction and pace of innovation, which underpins future productivity growth; (3) by stimulating the formation of new businesses, which expands and strengthens the cluster itself. This impact of clusters on the competitiveness of involved members and the

4 Within Šumadija and Zapadna Srbija region, biggest areas under raspberries are in the municipalities Ivanjica (1,249 hectares) and Arilje (1,226 hectares) (SORS (2012, internal data).

EP 2016 (63) 4 (1417-1431) 
region in which cluster operates, is widely accepted in domestic and foreign literature on clusters, as well as in documents of national and international institutions and organizations that deal with clusters.

Many authors indicate the positive effects of cluster networking in sector of agriculture and rural areas. For example, Gibbs and Bernat (1997), point out that labor is expected to be more productive within clusters, which should translate into higher wages (the analysis of these authors shows that workers' earnings in rural industry clusters are about 13 percent higher than those of comparable workers outside clusters). Henry et al., (1997) find a positive association between the extent of clustering and income growth in rural regions. The group of authors (Porter et al., 2004) exploring competitiveness in rural U.S. regions, indicate the following: (a) viewing regional economies in terms of clusters is central to understanding the competitiveness of rural areas and how it can be improved; (b) across all rural regions in USA most clusters are growing and rural regions have grown employment faster than metro areas in most clusters; (c) each rural area will differ in its cluster composition and in the opportunities created by the cluster strengths in nearby metropolitan areas.

Clusters are particularly important in agriculture sector and rural areas in developing countries and transition ones, where they should be significant instrument for shifting the focus of competitiveness, from factor or comparative advantages (low transportation, low cost of labor and land, high-quality natural resources) to "new" sources of sustainable competitive advantage (productivity growth, knowledge, innovation, cooperation, technologies, etc.). According to Liefert and Swinnen (2002, page 28), "for transition countries productivity growth in agriculture is more important factor than the growth of agricultural production. Productivity growth involves changing not just the material technology of production, but more importantly the nature and behavior of farms (how they are organized, managed, and motivated), and creating the supporting commercial and public infrastructure and institutions that a market-driven agricultural system needs".

In Serbian economy (and agribusiness) many clusters are legally registered, but in practice they are not operative, they are underdeveloped and weak, or they are in the initial stage of development with undeveloped trust and cooperation between participants (Mijačić, 2011; Paraušić et al., 2013; Paraušić, Cvijanović, 2014).

Regarding the contribution of clusters to creating sustainable competitive advantage of participating members, below are examined market opportunities for develop of cluster in sector of raspberry production in Šumadija and Western Serbia region. The analysis of competitive strengths and weaknesses of Serbian producers of raspberries has identified factors that are favorable for, and factors that discourage the successful cluster development in selected region.

For cluster development authors use the term Cluster Initiative (CI), which is more appropriate for this research. Although CI is often identified with clusters (empirical or market phenomenon of grouping the companies and institutions as a result of 
entrepreneurial spirit and action of market forces), in developing countries and transition ones, clusters are developed through CI. They are defined as public and private initiatives or as organized efforts to increase growth and competitiveness of clusters within a region, through joint activities of companies, governments and scientific research institutions (Sölvell et al., 2003; EC, 2008).

\section{Assessing competitive strengths and weaknesses of raspberry producers in Šumadija and Western Serbia region}

Advantages or factors favorable for successful formation of CI in raspberry sector in Šmadija and Western Serbia region that can contribute to competitive advantage of these producers on international market include:

- Serbia is the world's leading producer of raspberries and world's leading exporter of frozen raspberries (FAOSTAT, ITC).

- Raspberry is an important and leading export product of Serbian economy (SORS, 2016).

- Concentration of raspberry producers and cold storages and existence of a critical mass of participants in analyzed region. Arilje municipalities (within analyzed region), with 4,092 raspberry producers (SORS, 2012) represents a hub of raspberry production in Serbia. Commercial raspberry growing is carried out in every village in that municipality and "Agricultural Innovation Center" Arilje estimate that about 15,000 workers are hired during the raspberry harvest season, and more than 100 cold storages, mostly of small capacities have been recorded (Paraušić, Simeunović, 2015).

- Existence of associations of cold storages and association of raspberry producers (Ibidem).

- Tradition in production. Tradition in raspberry production in Arilje municipality dates back to 1970 (Ibidem).

- Recognition of producers and regions on the world market. Raspberries from Serbia are prized worldwide for their color, unique taste and firmness (SIEPA).

- Raspberry from Arilje is a product with protected designation of origin. This advantage exporters do not use, because raspberries are exported in branded packaging of foreign wholesalers. Taking into account global trends in trade and inability of domestic producers to directly supply hypermarkets in Europe, export through international distribution companies which have exclusive supply of certain chain stores, is a necessity and in some way advantage because in this way many agents are avoided (Paraušić, Simeunović, 2015).

- Proximity to EU market (Ibidem).

- Favorable natural conditions (good climate conditions, land) for production 
and high quality of raspberry (Ibidem).

- Existence of numerous scientific and advisory institutions in Serbia and region: research institutes, universities, The Arilje Agricultural Innovation Center, certification bodies, agricultural extension services, Regional Development Agency of Šumadija and Pomoravlje etc. (Ibidem).

- Customer demand on the rise due to health benefits (Ibidem).

Factors that discourage CI of raspberry producers in Šumadija and Western Serbia region and reduce the possibility of these producers to gain sustainable competitive advantage on international market are given below:

- Raspberry supply chain is poorly organized, short, and ends by the nearest cool storage (Zaric et al., 2013; Djurković, 2012; Stojanović, Radosavljević, 2013; SDC, may 2009-april 2012). There is no adding a new value, through knowledge, work, and innovation (raspberry is mostly exported as a primary product, mainly frozen in bulk). According to the research of British Columbia (page 9) "due to a lack of processing technologies, Serbia consumes very small quantities in local juice and puree products and instead exports most of its broken and frozen raspberries to other European countries where firms process the raspberries for re-export".

- Lack of advanced vertical integration in the raspberry value chain (especially between agricultural producers, cold storages, and traders). Primary agricultural producers do not have ownership stakes in cold storages and specialized cooperatives for raspberry production and export are underdeveloped (Paraušić, Simeunović, 2015).

- Trust and cooperation between primary producers, cold storages, wholesalers, banks, Regional Development Agencies (RDAs) and government bodies, as a key component of clusters, are missing and it's difficult to build. Although cold storages provide raspberry producers the necessary inputs for production and often through these inputs finance the producers, there is a constant antagonism between cold storages, wholesalers, and primary agricultural producers in terms of price and conditions of purchase (Ibidem).

- Relatively low food-safety and quality-assurance standards (Stojanović, Radosavljević, 2013; British Columbia). However, on the basis of the raspberry price changes at the farm, group of authors note that the price is more influenced by some other factors (e.g. the demand conditions or power of the processors) than by introduction of the quality system (Zarić et al., 2013).

- Fragmented raspberry production. Raspberries are grown on small family owned farms on plots of land that average 0.24 hectares (SORS, 2012).

- Lower production in period 2012-2014, because of infected raspberry plantlets and floods in recent period (Pekić, 2015). 
- Raspberry is grown in the absence of irrigation measures, making it less effective (Sredojević et al., 2013). Also, Serbian raspberry growers have low levels of crop insurance coverage.

- Lack of machinery, technology and equipment in raspberry production, trade, and raspberry processing. "As most Serbian firms do not produce packaging material of adequate quality for the EU market, if buyers from other countries require raspberries to be packed in a specific size or style of packaging for retail purposes, they usually supply the packaging and labels to Serbian processors" (British Columbia).

- Lack of innovation (small role of science) in modernization and improvement of crop cultivation technology (Paraušić, Simeunović, 2015). For example, raspberry varieties and technologies for growing raspberries have not been changed for decades and scientific institutions do not provide adequate support to this sector (Pekić, 2015).

- Lack of knowledge about the functioning of fruit and vegetables foreign markets; lack of research and development in terms of new products and trends, new technologies (SDC). The largest part of the export products is actually initiated by the purchase of EU companies and there are few examples that domestic companies exporting the product to EU market (SEEDEV, 2010).

- Insufficient support for farmers, SMEs and clusters from the government, government agencies, Regional Development Agency of Šumadija and Pomoravlje. For example: expensive loans and underdeveloped financial market; unstable and unpredictable measures of agricultural policy; underdeveloped institutions of legislative and judicial power etc. (Paraušić, Simeunović, 2015).

- Underdeveloped physical infrastructure in hilly and mountainous areas, where raspberry production is concentrated, which reduces the possibility for foreign investments in this sector (Kljajić, et al., 2013).

\section{Conclusion and recommendations}

Clusters development initiatives are an important new instrument and direction for creating and strengthening competitiveness in the hands of business and political leaders. They can be developed in the agricultural sector and in the rural areas, and their contribution to improving the competitiveness of producers and regions clearly confirms the economic theory and practice.

Cluster development initiatives in raspberry sector in Šumadija and Western Serbia region may have an important role for economic strengthening of produces and rural development of whole region, only if numerous assumptions and prerequisites that authors present below are implemented, like:

- Better organized within raspberry sector and raspberry value chain by 
long term vertically and horizontal integration of all actors involved in the production, processing and selling of raspberries (input suppliers, growers, cold storages, processors, wholesalers/retailers, exporters, buyers, certification and government bodies, banks, Regional Development Agency etc.). Intensifying cooperation between participants can be achieved through training, by building mutual trust and awareness of the need for joint efforts and cooperation of all market actors, by linking primary producers and cold storages through ownership stake, etc.

- Strengthening specialized cooperatives for raspberry and raspberry producer groups, and in the future setting up of producer organisations and associations in this sector. Producer organisations and associations should be qualified as SMEs, and recognized by the Ministry of Agriculture and Environmental Protection. They establishment will depend on alignment with the acquis in the negotiation process for the accession of the Republic of Serbia to the EU and on the adopting of the Act on the Organisation of the Markets in Agricultural Products (КЕИ, 2014). EU regulation on support for rural development (No $1305 / 2013$ ), points out that "producer groups and organizations help farmers to face together the challenges posed by increased competition and consolidation of downstream markets in relation to the marketing of their products including in local markets".

- Inclusion of producers of related products in CI (horizontally connected producers that have the same distribution channels, same market, similar technology etc.). This refers to the inclusion of other berry producers (blueberries, currants, strawberries, and blackberries), producers of processed fruit (pasta, concentrate, purees, jams, juices, etc.) and so on.

- Introducing innovations, scientific knowledge, and research and development. Successful development of CI must involve modernization of raspberry production and improvements to manufacturing practices in way of introducing new varieties of raspberries (change of varieties grown), building modern plantations with irrigation system and anti-hail nets, introducing new technologies of planting, harvesting, packing, processing, logistics, export of raspberries. In these processes, the role of scientific and educational institutions (universities, institutes) and agricultural extension services is of great importance. All of this will lead to stable and high yields of raspberries, to extend growing season, lower costs, higher production and higher competitiveness of domestic producers on the international market.

- Introduction of food-safety and quality-assurance standards.

- Support from public-private organizations, especially Regional Development Agency, in different segment: analysis of the world market regarding raspberry production and export, an accurate basis to determine competitiveness of domestic producers and estimate how much foreign customers are willing 
to pay for higher quality of homemade raspberry, analysis of value chain of products, analysis of the competitive position of domestic producers of raspberries and so on. Also, support is needed in the area of training for producers, certification of production, participation on the trade fairs, transfer of market information and science research, etc.

- Support from government departments, bodies and agencies. Key role of public sector must be in the domain of creating a stimulating (favorable) business environment for agricultural holdings and SMEs: simulative and predictable agricultural policy, lowering taxes, adapting laws to the needs of the economy, building physical and business infrastructure etc.

- Support from the banking sector (favorable loans for the construction of cold storages, raspberry purchase, establishing modern plantations, etc.), advertising agencies, certification bodies and other supporting institutions.

Although clusters are not developed in Serbia, raspberry sector in Šumadija and Western Serbia region has a large potential for successful and sustainable CI development, which can be used only with solving all the listed limitations that discourage higher raspberry production and export. Also, development of cluster initiatives requires a large and common working of agricultural producers, processors, cold storages, traders, government, regional development agency, scientific research institutions, and other institution and organization.

\section{Literature}

1. British Columbia. "A Global Export Market Overview for British Columbia's Raspberry Industry", market analysis report (available at:http://www2.gov. bc.ca/assets/gov/farming-natural-resources-and-industry/agriculture-andseafood/statistics/exports/global_export_market_bcraspberries.pdf).

2. Cvejić, S., Babović, M., Petrović, M., Bogdanov, N., Vuković, O. (2010): Socijalna isključenost u ruralnim oblastima Srbije. UNDP, Srbija.

3. Djurković, M. (2012): SWOT analysis of Serbia's raspberry sector in the competitive marketplace, Norwegian University of Life Sciences, Master Thesis (available at: https://brage.bibsys.no/xmlui/bitstream/handle/11250/187406/ Djurkovic\%20Marina\%202012.pdf?sequence=1).

4. European Commission (2006): Putting knowledge into practice: A broad-based innovation strategy for the EU, European Commission, Brussels, $\mathrm{COM}(2006)$ 502 final.

5. European Commission (2008): The concept of clusters and cluster policies and their role for competitiveness and innovation: main statistical results and lessons learned. Commission Staff Working Document, SEC (2008) 2637.

6. Europe Innova (2008): Cluster policy in Europe: A bried summary of cluster policies in 31 European countries. Oxford Research AS. 
7. European Economic and Social Committee - EESC. (2011): Opinion of the European Economic and Social Committee on Rural Development and Employment in the West Balkan countries. Brussels, 21st September 2011, REX/322.

8. Gallup Organization (2006): 2006 Innobarometer on cluster's role in facilitating innovation in Europe, Analytical Report, July 2006, Flash Eurobarometer 187, European Commission (available at: http://cordis.europa.eu/innovation-policy/ studies/pdf/innobarometer_2006_en.pdf).

9. Gibbs, R. M. and Bernat Jr, G. A. (1997): Rural Industry Clusters Raise Local Earnings. Rural Development Perspectives vol. 12, No. 3, USDA Economic Research Service (available at: http://aalto.arch.ksu.edu/jwkplan/ruralsem/ clusters.pdf).

10. Henry, M., Barkley, D., Zhang, Y. (1997): Industry Clusters in the TVA Region: Do they affect development of rural areas? TVA Rural Studies Program/ Contractor Paper 98-9, Dec. 1997 (available at: http://www.uky.edu/Ag/ AgriculturalEconomics/pubs/tvahenry98-9.pdf).

11. Kancelarija za evropske integracije - KEI. (2014): Nacionalni program za usvajanje pravnih tekovina EU, (available at: http:/www.seio.gov.rs/ upload/ documents/nacionalna_dokumenta/npaa/npaa_2014_2018.pdf).

12. Kljajić, N., Vuković, P., Arsić, S. (2013): Tendencies related to the production of raspberries in Serbia. Economics of Agriculture. Publishers: Balkan Scientific Association of Agrarian Economists, Institute of Agricultural Economics, Belgrade and Academy of Economic Studies, Bucharest. No 1/2013, pages 3948, Belgrade.

13. Liefert W., Swinnen J. (2002): Changes in Agricultural Markets in Transition Economies, Agricultural Economic Report No. 806, March 2002, Washington, USDA Economic Research Service.

14. Mijačić, D. (2011): Analiza stanja poslovne infrastrukture u Republici Srbiji. Nacionalna agencija za regionalni razvoj.

15. OECD (2006): Business Clusters: Promoting Enterprise in Central and Eastern Europe, LEED Programme.

16. Paraušić, V., Simeunović, I. (2015): Survey with representatives participants in Serbian raspberry sector: (a) National of Fruit and Vegetable Growers Association "Plodovi Srbije"; (b) Cooperative "Eko voće", Arilje; (c) Association of raspberry producers "Vilamet", Arilje; (d) Local Economic Development Office, Arilje municipality; (e) Innovation center for Agriculture Arilje Ltd; (f) owner of the cold storage „Stanić“, Ltd, Arilje; (g) Serbia Investment and Export Promotion Agency, unpublished material.

17. Paraušić, V., Cvijanović, J. (2014): Konkurentnost agroprivrede Srbijeklasteri u funkciji održive regionalne konkurentnosti. Institut za ekonomiku poljoprivrede, Beograd. 
18. Paraušić, V., Cvijanović, J., Mihailović, B. (2013): Market analysis of clusters in Serbian agribusiness. Economics of Agriculture. Publishers: Balkan Scientific Association of Agrarian Economists, Institute of Agricultural Economics, Belgrade and Academy of Economic Studies, Bucharest, No. 4, pages 713728, Belgrade.

19. Pekić, V. (2015): Outlook of Serbian and Polish raspberry sectors, presentation. Talca, Chile, Avgust 2015. (available at: http://www.chilealimentos.com/ medios/2015/Berries/Pekic.pdf).

20. Porter, M. E. (1998): Clusters and the New Economics of Competition. Harvard Business Review, November-December, Harvard Business School Publishing, page 77-90.

21. Porter, E. M. (2008): On competition, Harvard Business Review Book.

22. Porter, M., Ketels, C., Miller, K., Bryden, R. (2004): Competitiveness in Rural U.S. Regions: Learning and Research Agenda, Institute for Strategy and Competitiveness, Harvard Business School, February 25, 2004 (available at: http://www.isc.hbs.edu/Documents/ced/EDA_RuralReport_20040621.pdf).

23. REGULATION (EU) No $1305 / 2013$ on support for rural development by the EAFRD and repealing Council Regulation (EC) No 1698/2005.

24. SEEDEV. Regional Agricultural Competitiveness Analysis of 15 Serbian Municipalities. Executive Summary (available at: http://lokalnirazvoj.rs/ assets/Executive\%20Summary\%20SEEDEV_ENG.pdf).

25. SEEDEV. (2010): Efekti liberalizacije carina na poljoprivredu Srbije. USAID Agrobiznis projekat (available at: http:/www.agrarije.com/sites/default/files/ Efekti\%20liberalizacije\%20na\%20poljoprivredu\%20Srbije.pdf).

26. SIEPA. Fruit Industry in Serbia. (available at: http://www.usz.gov.rs/files/ publikacije/FruitIndustryInSerbia.pdf).

27. Službeni glasnik RS, broj 15/2011. Nacionalni program ruralnog razvoja od 2011. do 2013. godine.

28. Sredojević, Z., Kljajić, N., Popović, N. (2013). Investing in Raspberry Production as an Opportunity of Sustainable Development of Rural Areas in Western Serbia. Economic Insights - Trends and Challenges, Vol. II, No. 1/2013, 63-72 (available at: http://www.upg-bulletin-se.ro/archive/2013-1/6. Sredojevic_Kljajic_Popovic.pdf).

29. Stojanović, Ž., Jovanović Gavrilović, B., Lončar, D., Janković, I., Ristić, B., Gligorić, M. (2015). Global and Local Raspberry Supply Chains: National Report of Serbia. Faculty of Economic, University of Belgrade (available at: http:/glamur.eu/wp-content/uploads/2015/04/glamur-wp3-serbia-raspberry-2cases.pdf).

30. Stojanović, Ž., Radosavljević, K. (2013). Food chain, agricultural competitiveness and industrial policy: a case study of the Serbian raspberry 
production and export, Ekonomika preduzeća, Savez ekonomista Srbije. Issue 3-4, pages 174-182, Beograd.

31. Swiss Agency for Development and Cooperation - SDC. Market analysis of the fruit sector in Zlatibor County, Serbia. May 2009-April 2012. (available at: http://www.value-chains.org/dyn/bds/docs/827/Market $\% 20$ analysis $\% 20$ of $\% 20$ The $\% 20$ Fruit $\% 20$ sector $\% 20$ in $\% 20$ Zlatibor $\% 20$ C.pdf).

32. Sölvell, Ö., Lindqvist, G, Ketels, C. (2003). The Cluster Initiative Greenbook. Ivory Tower AB, Stockholm.

33. US Council on Competitiveness (2007): Innovation America - Cluster-Based Strategies for Growing State Economies.

34. Zarić, V., Vasiljević, Z., Vlahović, B., Andrić, J. (2013). Basic Characteristics of the Raspberry Marketing Chain and Position of the Small Farmers in Serbia. 135th EAAE Seminar, Book of Proceddings "Challenges for the Global Agricultural Trade Regime After Doha”, August 2013. Belgrade, Serbia, pp. 359-368 (available at: http://ageconsearch.umn.edu/bitstream/160517/2/24Zaric,\%20Vasiljevic,\%20Vlahovic,\%20Andric\%20-\%20EAAE\%20135.pdf).

35. World Bank (2009). Clusters for Competitivenes: A Practical Guide and Policy Implications for Developing Cluster Initiatives. International Trade Department, February 2009.

\section{Statistical and internet sources:}

1. FAOSTAT (available at: http://faostat.fao.org, http://faostat3.fao.org/home/E).

2. International Trade Centre - ITC, Trade Map (available at: http:/www. trademap.org, http://www.trademap.org/Index.aspx).

3. International Raspberry Organization - IRO, Chile (available at: http:/www. internationalraspberry.net/contact-us), internal data.

4. Penn State Extension (available at: http://extension.psu.edu/business/agalternatives/horticulture/fruits/red-raspberry-production).

5. SORS (2016), (available at http://webrzs.stat.gov.rs/WebSite/Public/ ReportResultView.aspx? rptKey=indId\%3d170402IND01\%262\%3d201000\%2 c201100\%2c201200\%2c201300\%2c201400\%2c201500\%2613\%3d\%2612\% $3 d 00 \% 2661 \% 3 d 10 \% 266 \% 3 d 1 \% 2 c 2 \% 26$ sAreald $\% 3 d 170402 \% 26 d T y p e \% 3 d N$ ame\%26lType\%3dSerbianCyrillic).

6. Statistical Office of the Republic of Serbia - SORS (2015). Statistical Yearbook of the Republic of Serbia, Belgrade.

7. Statistical Office of the Republic of Serbia - SORS (2012). Census of Agriculture 2012 in the Republic of Serbia, internal data. 


\title{
TRŽIŠNA ANALIZA U SEKTORU PROIZVODNJE MALINA U SRBIJI I RAZVOJ KLASTERSKIH INICIJATIVA
}

\section{Vesna Paraušićc , Ivana Simeunovićc}

\begin{abstract}
Rezime
Autori analiziraju konkurentske snage i slabosti proizvođača malina u Srbiji i predlažu ključne pretpostavke od čijih ispunjenja će zavisiti razvoj uspešnih klaster inicijativa u proizvodnji malina u Srbiji. Rezultati istraživanja pokazuju da proizvođači malina mogu razviti uspešan klaster i zadržati voćeću poziciju na svetskom tržištu malina, jedino okoliko su ispunjene brojne pretpostavke, a neke od najvažnijih su sledeće: (a) efikasnije organizovan tržišni lanac maline, kroz verikalnu i horizontalnu integraciju svih aktera u ovom sektoru; (b) jačanje specijalizovanih zadruga i udruženja proizvođača malina $i$ u narednom periodu formiranje proizvođačkih organizacija $i$ asocijacija; (c) uključivanje u klaster proizvođača drugog bobičastog voća $i$ prerađivača ovih proizvoda; (d) veća uloga inovacija, naučnih znanja i istraživanja $i$ razvoja u proizvodnji, preradi, pakovanju, lostitici, izvozu malina i sl. Analiza je zasnovana na studiji slučaja u regionu Šumadije $i$ Zapadne Srbije, s obzirom da je ovo glavni i najznaćajniji region u proizvodnji malina u Srbiji.
\end{abstract}

Ključne reči: klaster inicijativa, konkurentska prednost, sektor proizvodnje malina, lanac vrednosti maline.

5 Dr Vesna Parausić, naučni saradnik, Institut za ekonomiku poljoprivrede, Volgina ulica br. 15, 11060 Beograd, Srbija, Telefon: +381 116972 847, E-mail: vesna_pa@iep.bg.ac.rs.

6 Dr Ivana Simeunović, vanredni profesor, Beogradska bankarska akademija, Fakultet za bankarstvo, osiguranje i finansije, Zmaj Jovina ulica br. 12, 11000 Beograd, Telefon: +381 112627 272, E-mail: ivana.simeunovic@bba.edu.rs.

EP 2016 (63) 4 (1417-1431) 